Vol 12, Issue 1, 2019

\title{
BIOACTIVITY-GUIDED PHYTOCHEMICAL INVESTIGATIONS OF ARTEMISIA MARITIMA: ISOLATION AND CHARACTERIZATION OF CHEMICAL CONSTITUENTS
}

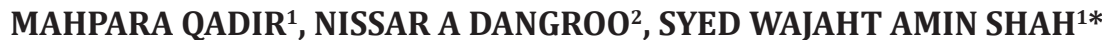 \\ ${ }^{1}$ Department of Chemistry University of Kashmir, Hazratbal, Srinagar, Jammu and Kashmir, India. ${ }^{2}$ Department of Chemistry, National \\ Institute of Technology, Srinagar, Jammu and Kashmir, India. Email: doctorwajaht@gmail.com
}

Received: 19 July 2017, Revised and Accepted: 22 October 2018

\section{ABSTRACT}

Objective: In the present study, the extracts (petroleum ether and methanolic extract) of plant Artemisia maritima were subjected to bioactivity evaluation and compound isolation and characterization.

Methods: Antioxidant activity was carried out using ferric reducing power and 2,2-diphenyl-1-picrylhydrazyl (DPPH) assay. The anticancer activity was evaluated by MTT assay using three different human cancer cell lines: Embryonic kidney cancer cell (HEK), lung adenocarcinoma epithelial cell (A-549), and human colon cancer cell (HCT), and isolated compounds were characterized using nuclear magnetic resonance $\left({ }^{1} \mathrm{HNMR}\right)$, ${ }^{13} \mathrm{CNMR}$, DEPT, infrared, and mass spectroscopic techniques.

Results: The petroleum ether extract of the plant displayed significant antioxidant and cytotoxic effects, which on phytochemical analysis led to the isolation of two bioactive sesquiterpene lactone compounds. These phytochemicals were identified using different spectral techniques in the light of literature. All the compounds displayed significant cytotoxic activity; however, compound-1 exhibited potent anticancer activity with inhibitory concentration value of $17.3 \mu \mathrm{g} / \mathrm{mL}$. The isolated compounds also displayed significant antioxidant potential.

Conclusion: Artemisia maritima, a rich source of sesquiterpene lactone which may be responsible for significant anticancer potential and it also possess remarkable antioxidant activity and hence may be of immense importance to food Chemistry.

Keywords: Artemisia maritima, Phytochemical investigation, Isolation, Cytotoxicity, Antioxidant activity.

(C) 2019 The Authors. Published by Innovare Academic Sciences Pvt Ltd. This is an open access article under the CC BY license (http://creativecommons. org/licenses/by/4. 0/) DOI: http://dx.doi.org/10.22159/ajpcr.2019.v12i1.28600

\section{INTRODUCTION}

The genus Artemisia (family: Asteraceae) is one of the most widely distributed and largest genus comprising around 500 species which are distributed mainly in the temperate zones of Europe, Asia, and North America. Of these, 32 species occur in India. Artemisia species possess pharmacological properties that are used for medical purposes worldwide. These species are known for their chemical constituents that are extensively used in food and pharmaceutical industry [1-3]. Literature reveals the isolation of artemin, 1-Keto- $6 \beta, 7 \alpha, 11 \beta-4(5)$ en-6, 12-olide, vulgarin, and maritimin from the aerial parts of Artemisia maritime $[4,5]$. Camphor and 1,8-cineole have found to be the main constituents of essential oil of this plant and also the antibacterial, antifungal, mosquito biting deterrent, and larvicidal activities of this oil have been evaluated [6]. The significance of the present study lies in the fact that bioactivity-guided isolation of aerial parts of A. maritima was carried out and it was found that pet ether extract was rich in phytochemicals exhibiting significant antioxidant and cytotoxic effects. Therefore, it was subjected to column chromatography and led to the isolation of two bioactive compounds. These isolated compounds were evaluated $1^{\text {st }}$ time for the cytotoxic effect against HEK, HCT, and A-549 cancer cell lines. The isolated compounds were also subjected to antioxidant evaluation using 2,2-diphenyl-1-picrylhydrazyl (DPPH) and ferric reducing assay.

\section{METHODS}

\section{Plant material collection}

Aerial parts of A. maritima were collected in July 2015 from high altitude area of Minjhe, Kargil Region of J and K (India) and were properly authenticated by Prof. A. R. Naqshi and curator Akhter Ahmed Malik of Taxonomy Department, University of Kashmir. A specimen under accession no. 2326-(KASH) was deposited in the herbarium of the institute.
Preparation of extracts

The plant material was finely chopped into small pieces, shade dried and powdered. The powdered material $(2.340 \mathrm{~g})$ was extracted with different solvents (hexane, chloroform, ethyl acetate, and methanol) of their increasing polarity using Soxhlet apparatus. Solvent was changed once a clear solution was obtained indicating that everything gets solubilized in that particular solvent. Solvent was removed from the extracts using rotary evaporator to afford crude extract. Preliminary antioxidant and cytotoxic screening of extracts revealed that petroleum ether extract to possess better antioxidant and cytotoxic effects, and subsequently, used for isolation of active chemical constituents.

\section{Isolation of compound}

$77 \mathrm{~g}$ of pet ether extract of the plant material was subjected to column chromatography using silica gel (60-120 mesh) to afford compounds using hexane-EtOAc as eluent with increasing polarity of $1 \%, 2 \%$, $5 \%$, and so on. Two compounds were obtained: Compound-1 and compound-2.

\section{Compound 1}

Light orange solid; mp: $123-126^{\circ} \mathrm{C}$; infrared (IR) vmax $\mathrm{cm}^{-1}: 1779$,

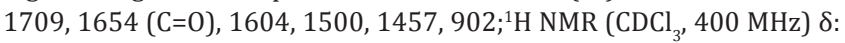
$4.51(1 \mathrm{H}, \mathrm{d}, J=12.0 \mathrm{~Hz}, \mathrm{H}-6), 2.41(1 \mathrm{H}, \mathrm{dq}, J=4.5,8.0 \mathrm{~Hz} . \mathrm{H}-12), 2.12(3 \mathrm{H}$, s, H-15), 1.90 (2H, m, H-9), 1.85 (1H, m, H-7). 1.82 and 1.51 (1H each, $\mathrm{m}$, $\mathrm{H}-8), 1.34$ (3H, s, H-14), 1.29 (3H, d, J = 8.0 Hz, H-13); ${ }^{13} \mathrm{C}$ NMR (101 MHz, $\left.\mathrm{CDCl}_{3}\right): \delta 213.50,178.46,129.63,127.00,81.80,52.94,48.87,41.01$, $36.00,34.83,31.90,23.93,23.48,19.80,12.33$

\section{Compound 2: Santonin}

Colorless crystalline solid; mp: $171-174^{\circ} \mathrm{C}$; IR $(\mathrm{KBr})$ vmax $\mathrm{cm}^{-1}: 1710$, 1685 (C=0), 1610, 1385, 1278, 820; 1H NMR (CDCl3, $400 \mathrm{MHz}) \delta$ : 
$6.69(1 \mathrm{H}, \mathrm{d}, J=8.0 \mathrm{~Hz}, \mathrm{H}-1), 6.25(1 \mathrm{H}, \mathrm{d}, J=8.0 \mathrm{~Hz}, \mathrm{H}-2), 4.80(1 \mathrm{H}, \mathrm{d}, J=12.0 \mathrm{~Hz}, \mathrm{H}-6)$, $2.41(1 \mathrm{H}, \mathrm{dq}, J=4.5,8.0 \mathrm{~Hz} . \mathrm{H}-12), 2.12(3 \mathrm{H}, \mathrm{s}, \mathrm{H}-15), 1.90(2 \mathrm{H}, \mathrm{m}, \mathrm{H}-9)$, 1.85(1H,m,H-7).1.82 and1.51 (1Heach, $\mathrm{m}, \mathrm{H}-8 \mathrm{~b}$ andH-8a), $1.34(3 \mathrm{H}, \mathrm{s}, \mathrm{H}-14)$, $1.29(3 \mathrm{H}, \mathrm{d}, J=8.0 \mathrm{~Hz}, \mathrm{H}-13) ;{ }^{13} \mathrm{C}$ NMR $\left(\mathrm{CDCl}_{3}, 125 \mathrm{MHz}\right) \delta: 186.33,177.64$, $154.96,151.05,128.69,125.87,87.40,53.54,41.38,41.01$, 37.85, 25.1516, $23.07,12.51,33.74$.

\section{Bioactivity evaluation of extract and isolated compound Anticancer Activity \\ Cell lines and culture}

MTT (3-(4,5-dimethylthiazol-2-yl)-2,5-diphenyltetrZazolium bromide, a tetrazole) protocol was used to carry out the antiproliferative effect of the extracts and pure compounds. A sufficient number of exponentially growing cells were used for this purpose to avoid confluence of the culture during the treatment. The cell lines A-549, HCT, and HEK were seeded at $10^{4}$ cells/well and allowed to adhere for $12 \mathrm{~h}$.

\section{Cytotoxicity assay}

To find the optimum concentration at which the cell proliferation is inhibited due to the extract/isolated compounds in all the cell lines, different cells were treated within concentration range of 15.6-250 $\mathrm{\mu g} / \mathrm{mL}$. Dimethyl sulfoxide was used as an experimental control, as it was used for dilution of extracts. Mitomycin C was used as positive controls at a concentration of $1 \times 10^{-5} \mu \mathrm{g} / \mathrm{mL}$. After $48 \mathrm{~h}$ treatment, cell growth was evaluated by MTT assay $[7,8]$ was added to each well and the plates were incubated for $3 \mathrm{~h}$ at $37^{\circ} \mathrm{C}$ in the dark. The media was aspirated and $150 \mu \mathrm{L}$ of MTT solvent (4 mM HCl, 0.1\% Nonidet P-40, all in isopropanol) was added to each well to solubilize the formazan crystals. The absorbance of plates was measured on ELISA reader (Benchmark, BioRad) at a wavelength of $570 \mathrm{~nm}$. Each sample was run in triplicate.

\section{Antioxidant activity}

\section{DPPH free radical scavenging activity}

The capacity to scavenge DPPH free radicals was measured according to Burda method [9] reported previously. DPPH free radical scavenging activity (RSA) was evaluated by measuring the scavenging activity of the extract/isolated compounds on stable DPPH radical. $0.5 \mathrm{mM}$ solution of DPPH in methanol and a stock solution of extract $(10 \mathrm{mg} / \mathrm{mL})$ in methanol were prepared. Various concentrations $(12.5-250 \mu \mathrm{g} / \mathrm{mL})$ were added to $1 \mathrm{~mL}(0.5 \mathrm{mM} \mathrm{DPPH})$ and final volume was made up to $3 \mathrm{~mL}$ with methanol. The mixture was shaken thoroughly, covered, and left in the dark at room temperature for $30 \mathrm{~min}$. The degree of declaration of methanolic DPPH solution indicates the scavenging efficiency. Absorbance of the mixture was measured at $517 \mathrm{~nm}$ on a spectrophotometer. A decrease in the absorbance indicates an increase in DPPH-RSA that is reduction in the number of DPPH radicals. Experiments were performed in triplicate. The radical scavenging effect was calculated by the following equation:

DPPH radical scavengingeffect $(\%)=([$ Acontrol - Bsample $] /$ Acontrol $] \times 100)$

Where, A control is the absorbance of the blank sample and B sample is the absorbance of the essential oil. L-ascorbic acid served as positive control. The percentage of scavenging activity was plotted against the oil concentration. The reaction involved is as follows:

$\mathrm{DPPH}+\mathrm{Oil}=\mathrm{DPPH}_{2}+$ Oil radical

(Purple colored) (Yellow colored)

\section{Reducing power assay}

Reducing power of the extract was performed through Oyaizu [10] method. The plant extract $(10-100 \mu \mathrm{g} / \mathrm{mL})$ was mixed with $2.5 \mathrm{~mL}$ $(0.2 \mathrm{M})$ sodium phosphate buffer $(\mathrm{Ph} 6.6)$ and $2.5 \mathrm{~mL}(1 \% \mathrm{w} / \mathrm{v})$ potassium ferricyanide $\mathrm{K}_{3} \mathrm{Fe}(\mathrm{CN})_{6}$. The resulting mixture was vortex mixed and incubated at $50^{\circ} \mathrm{C}$ for $20 \mathrm{~min}$, followed by the addition of $2.5 \mathrm{~mL}$ of tricarboxylic acid $(10 \% \mathrm{w} / \mathrm{v})$. The mixture was centrifuged at $3000 \mathrm{rpm}$ for $10 \mathrm{~min}$ to collect the upper layer of the solution $(2.5 \mathrm{~mL})$ which was then mixed with $2.5 \mathrm{~mL}$ distilled water and $0.5 \mathrm{Ml}$ of FeCl3 $(0.1 \% \mathrm{w} / \mathrm{v})$. Using ascorbic acid as positive control, absorbance was read at $700 \mathrm{~nm}$ against blank sample using spectrophotometer (UV-1650 PC; Shimadzu). The blank was solution with all reagents without extract. A higher absorbance value indicates a higher reducing power. The following equation was used for the calculation of reducing power:

Reducing power $(\%)=(1-[1-$ absorbance of control/absorbance of sample]) $\times 100$

\section{RESULTS AND DISCUSSION}

\section{Phytochemistry}

Phytochemical investigation of petroleum ether extract led to the isolation of two compounds: Compound 1 and 2. Compounds were characterized using spectral data and the comparison of data with that reported in the literature.<smiles>CC1=C2C3OC(=O)[C@@H](C)[C@H]3CC[C@]2(C)C(=O)CC1</smiles><smiles>CC1=C2[C@@H]3OC(=O)[C@@H](C)[C@H]3CC[C@]2(C)C=CC1=O</smiles>

\section{Compound 1}

\section{Compound 2 (Santonin)}

\section{Compound 1}

The compound was obtained as light orange solid with melting point $123-126^{\circ} \mathrm{C}$. The compound displayed a molecular ion peak at $\mathrm{m} / \mathrm{z}$ $249.021[\mathrm{M}+\mathrm{H}]^{+}$in liquid chromatography-mass spectrometry (LCMS), consistent with molecular formula of $\mathrm{C}_{15} \mathrm{H}_{18} \mathrm{O}_{3}$. IR spectrum showed the presence of $\Upsilon$-lactone at $1779 \mathrm{~cm}^{-1}$, ketone at $1709 \mathrm{~cm}^{-1}$, and enone at $1654 \mathrm{~cm}^{-1}$. The ${ }^{1} \mathrm{H}$-NMR spectrum (shown in Fig. 1) displayed signals for three methyl at $\delta_{\mathrm{H}} 1.23\left(3 \mathrm{H}, \mathrm{d}, J=7.6 \mathrm{~Hz}, \mathrm{CH}_{3}-13\right), 1.31\left(3 \mathrm{H}, \mathrm{s}, \mathrm{CH}_{3}-14\right)$, and $1.94\left(3 \mathrm{H}, \mathrm{s}, \mathrm{CH}_{3}-15\right)$, oxymethine signal at $4.58(1 \mathrm{H}, \mathrm{d}, J=12.0 \mathrm{~Hz})$ represents a translactone assignable to $\mathrm{CH}-6$, methine signals at $2.45(1 \mathrm{H}, \mathrm{dq}, J=4.5,8.0 \mathrm{~Hz})$ and $1.89(1 \mathrm{H}, \mathrm{m})$ were assignable to $\mathrm{CH}-12$ and $\mathrm{CH}-7$. The ${ }^{13} \mathrm{C}$ NMR-DEPT spectrum of the compound indicated 15 carbon signals including three methyl, two methylene, five methine, and five quaternary carbon atoms. The chemical shifts at $\delta C 213.51$ and 178.64 assignable to ketone carbonyl C-1 and lactone carbonyl C-11, and 129.63 and 127.00 were assignable to C-4 and $\mathrm{C}-5$, respectively. A typical signal at 81.80 is assignable to oxygenated C-6. This data suggested that the compound is a eudesmanolide type sesquiterpene scaffold. From the spectral evidence and comparing the physical data with the literature values, the compound 2 was identified as 1-keto-6 $\beta, 7 \alpha, 11 \beta$-H-selin-4(5)-en-6,12-elide [5].

\section{Compound-2: Santonin}

The compound was obtained as white crystalline solid with melting point $170-172^{\circ} \mathrm{C}$. The compound displayed a molecular ion peak at $\mathrm{m} / \mathrm{z} 247.1214$ $(\mathrm{M}+\mathrm{H})+$ in LCMS, consistent with molecular formula of $\mathrm{C}_{15} \mathrm{H}_{18} \mathrm{O}_{3}$. IR spectrum showed the presence of lactone $\left(1786 \mathrm{~cm}^{-1}\right.$ and enone $\left(1654 \mathrm{~cm}^{-1}\right)$. The 1H-NMR spectrum (as shown in Fig. 2) displayed signals for three methyl at $\delta \mathrm{H} 1.29(3 \mathrm{H}, \mathrm{d}, J=8.0 \mathrm{~Hz}, \mathrm{CH} 3-13), 1.34(3 \mathrm{H}, \mathrm{s}, \mathrm{CH} 3-14)$, and $2.12(3 \mathrm{H}$, $\mathrm{s}, \mathrm{CH} 3-15)$, two olefinic methine signals $6.70(1 \mathrm{H}, \mathrm{d}, J=8.0 \mathrm{~Hz})$ and $6.25(1 \mathrm{H}, \mathrm{d}, J=8.0 \mathrm{~Hz})$ assignable to $\mathrm{CH}-1$ and $\mathrm{CH}-2$, oxymethine signal at $4.80(1 \mathrm{H}, \mathrm{d}, J=12.0 \mathrm{~Hz})$ represents a translactone assignable to $\mathrm{CH}-6$, methine signals at $2.41(1 \mathrm{H}, \mathrm{dq}, J=4.5,8.0 \mathrm{~Hz})$ and $1.85(1 \mathrm{H}, \mathrm{m})$ were assignable to CH-12 and CH-7. The 13C NMR-DEPT spectrum of the compound indicated 


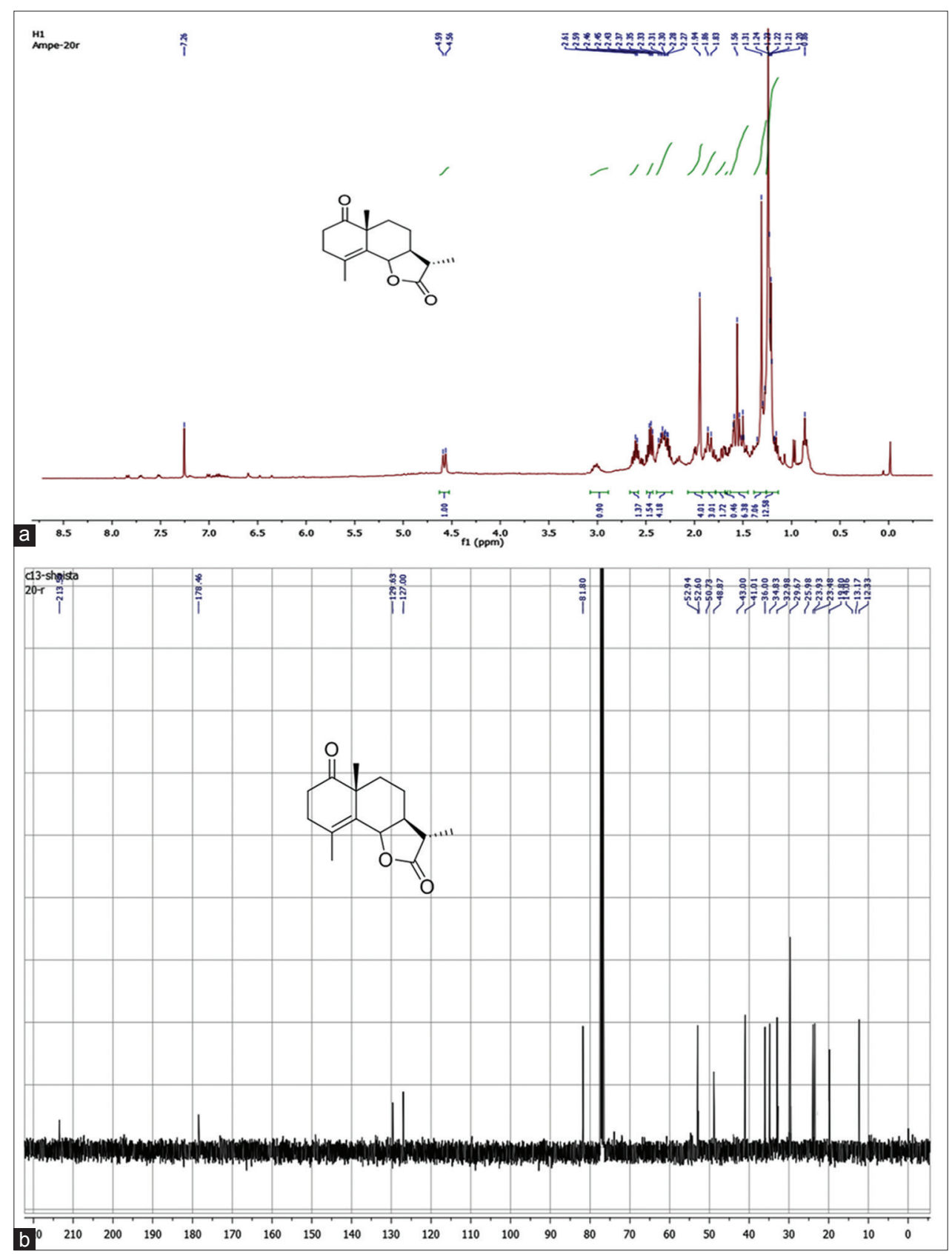

Fig. 1: (a and b) ${ }^{1} \mathrm{H}$ NMR and ${ }^{13} \mathrm{C}$ NMR of compound 1 (20r)

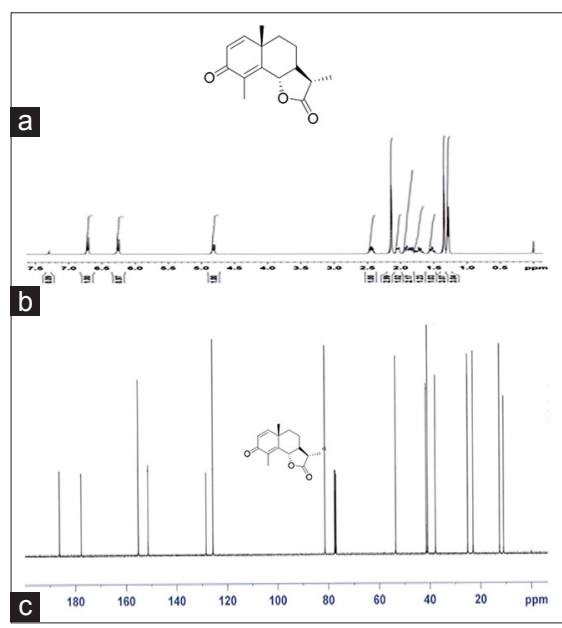

Fig. 2: (a-c) ${ }^{1} \mathrm{H}$ NMR and ${ }^{13} \mathrm{C}$ NMR of Compound 2 (santonin)
15 carbon signals including three methyl, two methylene, five methine, and five quaternary carbon atoms. The chemical shifts at $\delta C 186.33$ and 177.64 assignable to ketone carbonyl C-3 and lactone carbonyl C-11, and 154.96 and 125.87 were assignable to $\mathrm{C}-1$ and $\mathrm{C}-2$, respectively. A signal at 81.40 is assignable to oxygenated C-6. Three quaternary signals at 151.0,128.69, and 41.38 were assignable to $\mathrm{C}-4, \mathrm{C}-5$, and $\mathrm{C}-10$ suggested a eudesmanolide type sesquiterpene scaffold with dienone system. From the spectral evidence and comparing the physical data with the literature values, the compound 1 was identified as $\alpha$-santonin [11].

\section{Biological evaluation}

Anticancer activity

To understand the anticancer potential of A. maritima extract on human cancer cell lines, the petroleum ether, methanolic extract, and isolated compounds of pet ether extract were evaluated against three human cancer cell lines using lung, HCT, and HEK cancer cell lines by MTT assay (Table 1). All the tested samples were found to be active. However, highest activity of petroleum ether was found 
Table 1: In vitro anticancer activity of Artemisia maritime

\begin{tabular}{|c|c|c|c|c|c|c|}
\hline Tissue type & Lung & & Embryonic kidney & & Colon cancer cell line & \\
\hline Cell line type & A-549 & & HEK & & HCT & \\
\hline \multicolumn{7}{|l|}{ Extract } \\
\hline Concentration $\mu \mathrm{g} / \mathrm{mL}$ & $\%$ growth inhibition & $\mathrm{IC}_{50}(\mu \mathrm{g} / \mathrm{mL})$ & $\%$ growth inhibition & $\mathrm{IC}_{50}(\mu \mathrm{g} / \mathrm{mL})$ & $\%$ growth inhibition & $\mathrm{IC}_{50}(\mu \mathrm{g} / \mathrm{mL})$ \\
\hline \multicolumn{7}{|l|}{ Petroleum ether extract } \\
\hline 15.6 & 29.4 & 50.2 & 22.4 & 42.8 & 20.8 & 46.5 \\
\hline 31.25 & 40.1 & & 28.9 & & 29.8 & \\
\hline 62.5 & 64.1 & & 50.1 & & 54.9 & \\
\hline 125 & 71.3 & & 72.6 & & 70.9 & \\
\hline 250 & 76.0 & & 87.2 & & 75.1 & \\
\hline \multicolumn{7}{|l|}{ Methanolic extract } \\
\hline 15.6 & 31.8 & 44.6 & 38.6 & 49.0 & 36.6 & 43.3 \\
\hline 31.25 & 37.3 & & 42.3 & & 38.5 & \\
\hline 62.5 & 49.2 & & 55 & & 46.2 & \\
\hline 125 & 53.8 & & 58.8 & & 54.8 & \\
\hline 250 & 60.9 & & 63.2 & & 57.75 & \\
\hline
\end{tabular}

A. maritime: Artemisia maritime

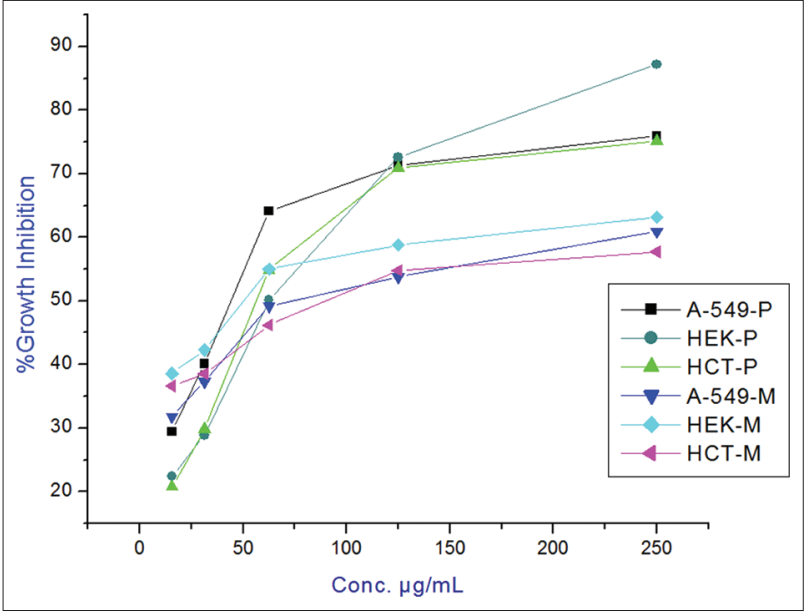

Fig. 3: In vitro cancer activity of petroleum ether and methanolic extract of Artemisia maritima

against HEK cancer cell line with inhibitory concentration $\left(\mathrm{IC}_{50}\right.$ ) value of $42.8 \mu \mathrm{g} / \mathrm{mL}$, and methanol extract was found against HCT with $\mathrm{IC}_{50}$ value of $43.3 \mu \mathrm{g} / \mathrm{mL}$ as is evident from the graph. The anticancer activity of this extract is reported $1^{\text {st }}$ time to the best of our knowledge from this geographical area. Due to the high cytotoxic potential of this extract, it would, therefore, be of immense importance to pharmaceutics to replace synthetic ones, which may have certain side effects (Fig. 3).

Compound-1 showed highest cytotoxic effect against HEK cancer cell line with IC ${ }_{50}$ value of $17.3 \mu \mathrm{g} / \mathrm{mL}$ while as compound- 2 showed highest activity against lung cancer cell line with $\mathrm{IC}_{50}$ value of $45.0 \mu \mathrm{g} / \mathrm{mL}$ as shown in Figs. 4 and 5, respectively (Table 2).

\section{Antioxidant activity}

Two different antioxidant assays were used for the evaluation of RSA of extract as well as the pure compounds. As each antioxidant assay has different mechanism of action, as more than one method can provide better assessment of radical scavenging properties. DPPH free radical assay and ferric reducing power (FRP) were used to determine the RSA of A. maritime extract and isolated compounds.

\section{DPPH assay}

The compounds which are able display antioxidant effect in the extract will itself get oxidized and convert DPPH into $\mathrm{DPPH}_{2}$. The extent to which

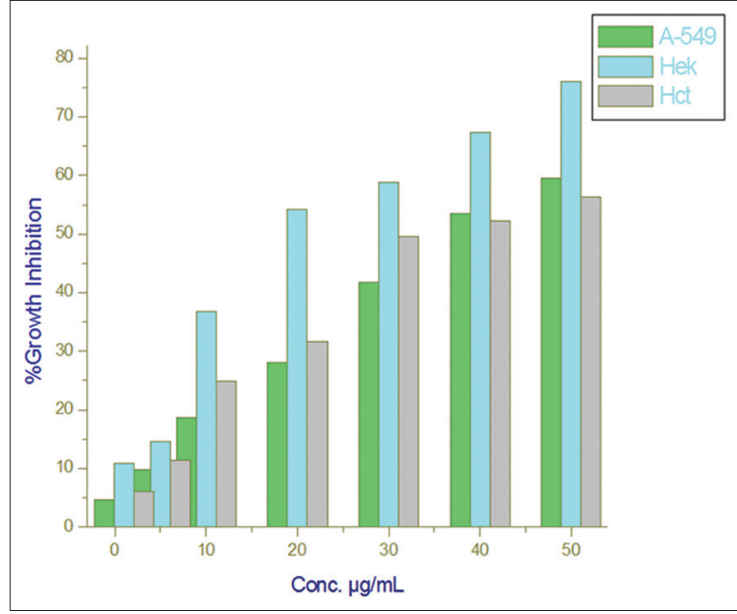

Fig. 4: In vitro cancer activity compound-1 of Artemisia maritime

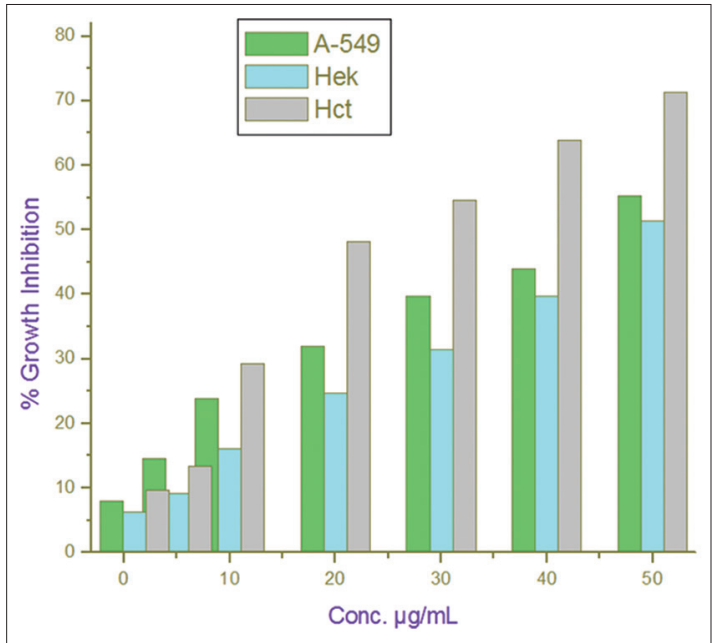

Fig. 5: In vitro cancer activity compound-2 of Artemisia maritima

this reaction happens is clearly observed due to decrease in absorbance measured at $517 \mathrm{~nm}$. The petroleum ether extract of A. maritima was found to be more active than methanolic extract and also the compounds isolated from pet ether extract showed potent antioxidant effects. $70.1 \%$ and $68.3 \%$ RSA of compound- 1 and compound- 2 were 
Table 2: In vitro cancer activity of compound-1 and compound-2 of Artemisia maritima

\begin{tabular}{|c|c|c|c|c|c|c|c|}
\hline \multicolumn{2}{|l|}{ Tissue type } & \multicolumn{2}{|l|}{ Lung } & \multicolumn{2}{|c|}{ Embryonic kidney } & \multicolumn{2}{|c|}{ Colon cancer cell } \\
\hline \multicolumn{2}{|l|}{ Cell line type } & \multicolumn{2}{|l|}{ A-549 } & \multicolumn{2}{|l|}{ HEK } & \multicolumn{2}{|l|}{ HCT } \\
\hline $\begin{array}{l}\text { Compound } \\
\text { type }\end{array}$ & Concentration $\mu \mathrm{g} / \mathrm{mL}$ & $\begin{array}{l}\text { \% Growth } \\
\text { inhibition }\end{array}$ & $\mathrm{IC}_{50}(\mu \mathrm{g} / \mathrm{mL})$ & $\begin{array}{l}\% \text { Growth } \\
\text { inhibition }\end{array}$ & $\mathrm{IC}_{50}(\mu \mathrm{g} / \mathrm{mL})$ & $\begin{array}{l}\% \text { Growth } \\
\text { inhibition }\end{array}$ & $\mathrm{IC}_{50}(\mu \mathrm{g} / \mathrm{mL})$ \\
\hline \multirow{6}{*}{ Compound-1 } & 1.0 & 4.6 & 36.9 & 10.8 & 17.3 & 6.09 & 30.7 \\
\hline & 5 & 9.8 & & 14.6. & & 11.4 & \\
\hline & 10 & 18.6 & & 36.7 & & 24.9 & \\
\hline & 30 & 41.7 & & 58.9 & & 49.5 & \\
\hline & 40 & 53.5 & & 67.3 & & 52.2 & \\
\hline & 50 & 59.6 & & 76.1 & & 56.4 & \\
\hline \multirow[t]{6}{*}{ Compound-2 } & 1.0 & 7.9 & & 6.3 & 48.0 & 9.6 & 50.05 \\
\hline & 5 & 14.6 & 45.0 & 9.08 & & 13.4 & \\
\hline & 10 & 23.8 & & 16.1 & & 29.2 & \\
\hline & 20 & 31.9 & & 24.7 & & 48.2 & \\
\hline & 30 & 39.7 & & 31.5 & & 54.6 & \\
\hline & 50 & 55.3 & & 51.4 & & 71.4 & \\
\hline
\end{tabular}

Table 3: Free RSA of $A$. maritima extracts and isolated compounds

\begin{tabular}{|c|c|c|c|c|c|}
\hline $\begin{array}{l}\text { Concentration } \\
(\mu \mathrm{g} / \mathrm{mL})^{\mathrm{a}}\end{array}$ & $\%$ RSA (pet ether) ${ }^{\mathrm{b}}$ & $\%$ RSA (methanolic) ${ }^{c}$ & $\%$ RSA (compound 1$)^{d}$ & \%RSA (compound 2) & $\%$ RSA (ascorbic acid) \\
\hline 10 & 8.64 & 3.8 & 15.6 & 10.8 & 46.4 \\
\hline 20 & 24.0 & 16.1 & 34.9 & 28.6 & 52.3 \\
\hline 30 & 40.5 & 31.5 & 46.5 & 42.1 & 60.8 \\
\hline 50 & 45.7 & 43.4 & 55.1 & 51.9 & 65.6 \\
\hline 70 & 54.3 & 48.3 & 67.03 & 59.7 & 75.4 \\
\hline 100 & 61.7 & 52.7 & 700.1 & 68.3 & 80.7 \\
\hline
\end{tabular}

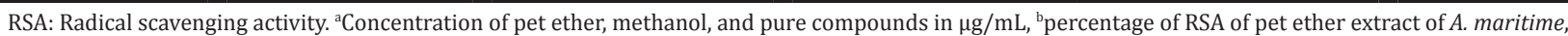
${ }^{c}$ percentage of RSA of methanolic extract of A. maritime, ${ }^{\mathrm{d}}$ percentage of RSA of compound 1 of $A$. maritime, ${ }^{\mathrm{e}}$ percentage of RSA of compound 2 of $A$. maritime, ${ }^{\mathrm{f}}$ percentage of RSA of positive control ascorbic acid. A. maritime: Artemisia maritime

Table 4: Ferric reducing activity of two extracts and isolated compounds of Artemisia maritima

\begin{tabular}{|c|c|c|c|c|c|}
\hline Concentration $(\mu \mathrm{g} / \mathrm{ml})$ & AMPE & AMME & Compound 1 & Compound 2 & Ascorbic acid \\
\hline 10 & 25.8 & 19.6 & 35.7 & 41.9 & 46.4 \\
\hline 20 & 28.8 & 23.3 & 38.3 & 46.3 & 52.3 \\
\hline 30 & 31.5 & 27.5 & 45.6 & 50.8 & 60.8 \\
\hline 50 & 38.63 & 33.8 & 49.2 & 54.1 & 65.6 \\
\hline 70 & 41.6 & 36.1 & 52.10 & 59.7 & 75.4 \\
\hline 100 & 45.00 & 38.4 & 58.00 & 63.4 & 80.7 \\
\hline
\end{tabular}

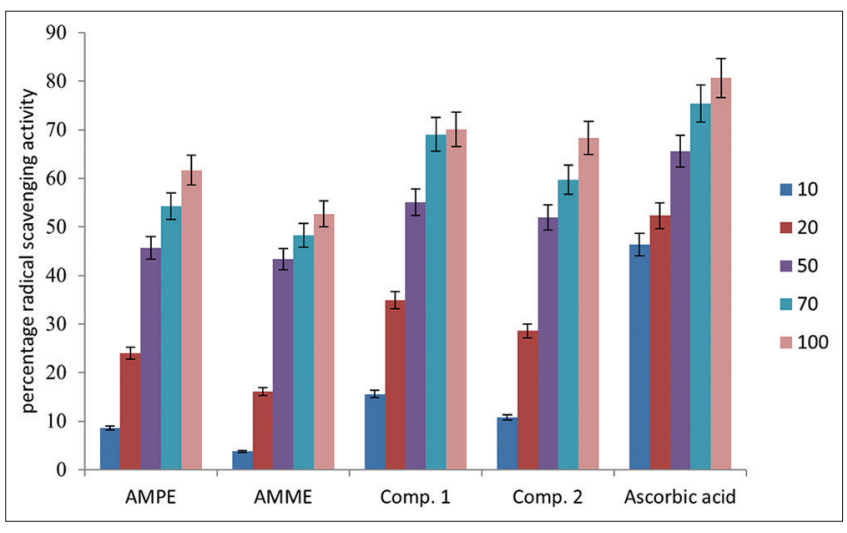

Fig. 6: 2,2-Diphenyl-1-picrylhydrazyl free radical scavenging activity of different extracts and isolated compounds of Artemisia maritima

observed at a concentration of $100 \mu \mathrm{g} / \mathrm{mL}$, respectively. Hence, this plant is a rich source of antioxidants (Table 3) [12-14].

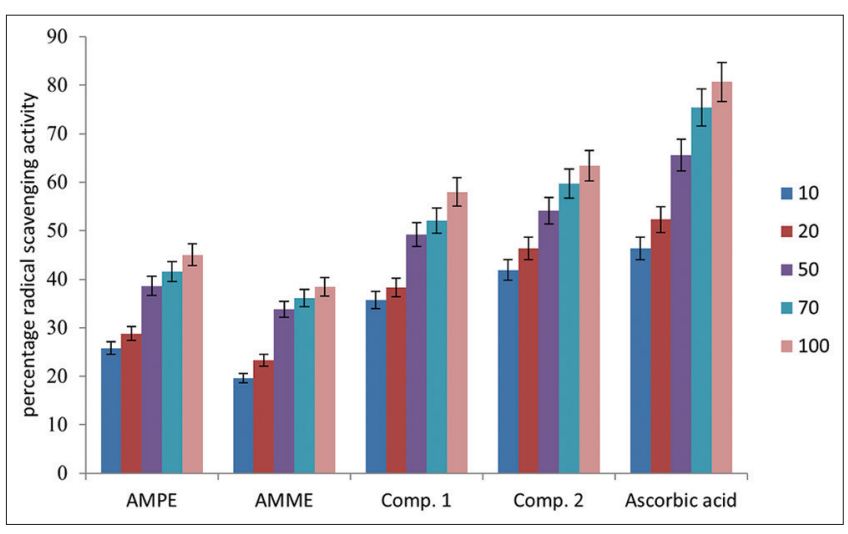

Fig. 7: Reducing power of extract and pure compounds

Reducing power assay

The FRP was evaluated by the ability of extract and pure compounds to convert ferric ion $\left(\mathrm{Fe}^{3+}\right)$ to ferrous $\left(\mathrm{Fe}^{2+}\right)$ involving a single electron transfer redox reaction. The following concentrations range was used 
to evaluate the antioxidant activity: $10,20,30,50,70$, and $100 \mu \mathrm{g} / \mathrm{mL}$. Results obtained were compared with the control ascorbic acid which showed maximum inhibition of $80.7 \%$ at a concentration of $100 \mu \mathrm{g} / \mathrm{mL}$. With increase in concentration, absorbance increases which indicates that increase on concentration increases reducing power. Due to this method also petroleum ether extract is found to be more active and compound-1, compound- 2 showed activity of 58 and $63.4 \%$, respectively, at a concentration of $100 \mu \mathrm{g} / \mathrm{mL}$ shown in Figs. 6 and 7, Table 4.

\section{CONCLUSION}

Artemisia maritima showed the presence of sesquiterpene lactones, the high anticancer and antioxidant potential of the isolated sesquiterpene lactones may be of immence potential to food chemistry. Hence these findings suggest that Artemisia maritime possess valuable pharmaceutical and important medicinal properties that may be used in future for various medical purposes.

\section{AUTHORS' CONTRIBUTIONS}

Mahpara Qadir has isolated the compound and carried out the biological activity of isolated compound and extract. Nissar A. Dangroo has characterized the compound. Wajaht A. Shah has designed the problem and wrote this article.

\section{CONFLICTS OF INTEREST}

We declare that we have no conflicts of interest.

\section{REFERENCES}

1. Kwak JH, Jang WY, Zee OP, Lee RK. A new coumarin-monoterpene ether from Artemisia keiskeana. Planta Med 1997;63:474-6.

2. Mehrdad I, Seyed EA, Meysam MS. Detection of sesquiterpene lactones in ten Artemisia species population of Khorasan provinces. Iran J Basic Med Sci 2007;10:183-8.
3. Watson LE, Bates PL, Evans TM, Unwin MM, Estes JR. Molecular phylogeny of subtribe artemisiinae (Asteraceae), including artemisia and its allied and segregate genera. BMC Evol Biol 2002;2:17.

4. Gonzalez AG, Bermejo J, Mansilla H, Massanet GM, Cabrera I, Amaro JM, et al. The structure and stereochemistry of artemin. Phytochemistry 1977;16:1836-7.

5. Gonzalez AG, Galindo A, Mansilla H, Guiterez A. Structure of maritimin, A sesquiterpene lactone from Artemisia maritima. Phytochemistry 1981;20:2367-9.

6. Stappen I, Wanner J, Tabanca N, Wedge DE, Ali A, Khan IA, et al. Chemical composition and biological effects of Artemisia maritima and Artemisia nilagirica essential oils from wild plants of Western Himalaya. Planta Med 2014;80:1079-87.

7. Alley MC, Scudiere DA, Monks A, Czerwinski MJ, Shoemaker RH, Boyd MR. Validation of an automated micro culture tetrazolium assay (MTA) to assess growth and drug sensitivity of human tumor cell lines. Proc Am Assoc Cancer Res 1986;27:389.

8. Alley MC, Scudiere DA, Monks A, Hursey ML, Czerwinski MJ, Fine DL, et al. Feasibility of drug screening with panels of human tumor cell lines using a micro culture tetrazolium assay. Cancer Res 1988;48:589-601.

9. Burda S, Oleszek W. Antioxidant and antiradical activities of flavonoids. J Agric Food Chem 2001;49:2774-9.

10. Oyaizu M. Studies on products of browning reactions prepared from glucosamine. Jpn J Nutr 1986;44:307-15.

11. Ruikar AD, Kulkarni MM, Phalgune UD, Puranik VG, Deshpande NR. GC-MS study and isolation of a sesquiterpene lactone from Artemisia pallens. Orient J Chem 2010;6:227-31

12. Adesegun SA, Fajana A, Orabueze CI, Coker HA. Evaluation of antioxidant properties of Phaulopsis fascisepala C.B.CI. Acanthaceae). Evid Based Complement Alternat Med 2009;6:227-31.

13. Sasikumar JM, Mathew GM, Teepica PD. Comparative studies on antioxidant activity of methanol extract and flavonoid fraction of Nyctanthes orbortristis leaves. Electron J Environ Agric Food Chem 2010;9:227-33.

14. Shah MD, Iqbal M. Antioxidant activity and phytochemical analysis and total polyphenolic content of essential oil and methanolic extract from Commelina nudiflora. Int J Pharm Pharm Sci 2018;10:36-43. 